\title{
FAKTOR-FAKTOR YANG MEMPENGARUHI EFEKTIVITAS PANGLIMA LAOT DALAM PENGELOLAAN SUMBER DAYA ALAM LAUT DI KOTA SABANG
}

\author{
Oleh: \\ Andri Kurniawan \\ Fakultas Hukum Universitas Syiah Kuala Aceh
}

\begin{abstract}
At Nanggroe Aceh Darussalam Province, regional domination pattern of sea still very strong grow in fisherman society. Therefore, in their society still functioned Panglima Laot that have the function to : defence and observe the sea for regional exploiting. In this case, the authoritative of Panglima Laot, first, maintaining the sea environment as cooperative ownership (common heritage). Second, arrange the resource management of the sea. Third, give the sanction to the people that collision to rule of the customary law of the sea. In Implementated their function, Panglima Laot have a lot of constraint, such as : the factor of fishing in sea, institution factor, the earningsinstitute factor, regional boundary factor, human resource factor, factor of the weakness management system in effort fishery, and also factor of supply of the traditional arrest.
\end{abstract}

Kata Kunci : Panglima Laot dan Pengelolaan SDA Laut

\section{A. Pendahuluan}

Masyarakat pesisir di seluruh Indonesia yang menggantungkan hidupnya dari kekayaan laut menggunakan pola penguasaan wilayah laut se-bagaimana halnya pola penguasaan wilayah darat (tanah). Meskipun tidak semua wilayah Indonesia menunjukkan praktik-praktik penguasaan wilayah laut, namun bukti-bukti menunjukkan adanya pola penguasaan wilayah laut yang tersebar dari ujung Barat (Aceh) sampai daerah Indonesia bagian Timur (Kei, Tanibar, dan Halmahera) dengan pola penguasaan yang bervariasi.

Aceh memiliki pola kelembagaan yang menempatkan panglima laot sebagai institusi dalam ketentuan/aturan yang lebih luas. Panglima laot menetapkan batas-batas ketentuan adat mengenai sistem pengelolaan sumber daya laut dan masalah-masalah pelaksanaan sosial dalam suatu ketetapan adat. Panglima laot memimpin kawasan-kawasan yang disebut dengan lhok. Lhok merupakan satuan lokasi tempat nelayan melabuhkan perahunya, menjual ikan atau berdomisili. Lhok biasanya berupa pantai atau teluk, bisa mencakup wilayah seluas sebuah desa/gampong, kecamatan/mukim, bahkan satu gugus kepulauan. Dengan menentukan tata batas dan tata kelola konservasi yang dari sana diterapkan hukum. Ke- tika aturan berjalan artinya ada kawasan yang berfungsi sebagai tempat untuk menjaga potensi eksploitatif (sumber daya Perikanan) dan non-eksploitatif (wisata alam bawah laut).

Berdasarkan hal di atas, maka Pemerintah Daerah mengeluarkan Peraturan Daerah Nomor 7 tahun 2000 tentang penyelenggaraan kehidupan adat. Adat istiadat dan kebiasaankebiasaan yang masih berlaku, hidup dan berkembang dalam masyarakat Aceh, sepanjang tidak bertentangan dengan syariah islam harus dipertahankan. Lembaga-lembaga adat yang hidup dan berkembang dalam masyarakat di daerah tetap dipertahankan, dimanfaatkan, dipelihara, diberdayakan dan dibakukan. Lebih lanjutnya, Perda ini menentukan bahwa lembaga adat (termasuk panglima laot) berfungsi sebagai alat kontrol keamanan, ketentraman, kerukunan, dan ketertiban masyarakat, baik preventif maupun represif, antara lain:

1. Menyelesaikan masalah sosial kemasyarakatan

2. Penengah (Hakim Perdamaian) mendamaikan sengketa yang timbul di masyarakat.

Dalam perkembangan akhir-akhir ini semakin sering dibicarakan keberadaan masyarakat hukum adat. Lembaga hukum adat yang dahulunya memiliki kedudukan dan fungsi yang sangat besar dalam penyelesaian berbagai 
206 Jurnal Dinamika Hukum

Vol. 8 No. 3 September 2008

masalah yang terjadi dalam masyarakat Aceh. Disamping hukum positif berkembang pula norma-norma yang timbul dari keputusan peutua adat yang mempunyai kekuasaan dalam masyarakat adat. Kedudukan dan perkembangan norma adat yang demikian berjalan terus sesuai dengan keadaan, tuntutan masyarakat dalam perkembangan modern. Apalagi dalam Pasal 6 Undang-Undang Nomor 31 Tahun 2004 tentang Perikanan, disediakan porsi yang sama bagi perangkat adat laot. Tinggal bagaimana aturanaturan adat ini mendapatkan legitimasi hukum pelaksanaannya.

Sementara itu, dalam Undang-Undang No. 11 Tahun 2006 tentang Pemerintahan Aceh (UUPA). Keberadaan lembaga adat (termasuk Panglima Laot) mendapatkan pengaturan tersendiri dalam Pasal 98 dan 99 BAB XIII tentang Lembaga Adat. Pasal 98 Ayat (2) menyatakan bahwa penyelesaian permasalahan sosial kemasyarakatan secara adat ditempuh melalui lembaga adat. Hal ini berarti fungsi penyelesaian sengketa masyarakat dari panglima laot tetap mendapatkan pengakuan. Untuk membangun kembali (revitalisasi) Hukum Adat Laot, khususnya budaya adat Aceh kiranya perlu memaknai kembali (re-thinking) arti dan tujuan sebuah budaya dan memfungsikan Panglima Laot dalam menyelesaikan sengketa-sengketa yang terjadi di laut.

Berdasarkan hal tersebut diatas, maka tulisan ini dibuat untuk menjelaskan permasalahan tentang faktor-faktor yang mempengaruhi efektivitas Panglima Laot dalam pengelolaan sumber daya alam laut di Kota Sabang.

\section{B. Pembahasan}

\section{Keberadaan Lembaga Panglima Laot Kota} Sabang

Kota Sabang merupakan kota yang terletak di Pulau Weh dengan luas wilayahnya \pm $153 \mathrm{KM}^{2}$, jumlah penduduk yang tercatat berdasarkan data Badan Pusat Statistik (BPS) Kota Sabang tahun 2006 adalah 28.657 jiwa, secara struktur pemerintahan, Kota Sabang terdiri dari 2 (dua) Kecamatan yaitu Kecamatan Sukakarya dan Kecamatan Sukajaya dengan 18 Kelurahan yang kondisi geografisnya disebelah utara dan timur berhadapan dengan Selat Malaka dan disebelah selatan dan barat berhadapan dengan Samudera Indonesia, dari kondisi geografisnya yang dikelilingi oleh lautan, maka di Kota Sabang cukup banyak terdapat teluk atau kualakuala disekeliling wilayah pantainya, wilayah hukum adat panglima laot di Kota Sabang dengan wilayah hukum meliputi seluruh pulau weh (wilayah pemerintahan Kota Sabang) dan 10 wilayah panglima lhok.

2. Lembaga Panglima Laot Lhok Di Kota Sabang

a. Panglima Laot Wilayah Pasiran

Wilayah hukum Panglima Laot Pasiran meliputi 4 Kelurahan yaitu:

1) Kelurahan Kota Bawah Timur

2) Kelurahan Kota Bawah Barat

3) Kelurahan Krueng Raya

4) Kelurahan Aneuk Laot

b. Panglima Laot Wilayah Pria Laut

Wilayah hukum Panglima Laot Pria laut meliputi 2 Kelurahan yaitu:

1) Kelurahan Batee Sok

2) Kelurahan Paya Seunara

c. Panglima Laot Wilayah Iboih meliputi satu kelurahan yaitu kelurahan Iboih

d. Panglima Laot Wilayah Balohan meliputi satu kelurahan yaitu Kelurahan Balohan

e. Panglima Laot Wilayah Jaboi meliputi satu kelurahan yaitu kelurahan yaitu Kelurahan Jaboi

f. Panglima Laot Wilayah Berawang meliputi satu kelurahan yaitu Kelurahan Berawang

g. Panglima Laot Wilayah Kenekai meliputi satu kelurahan yaitu Kelurahan Keunekai

h. Panglima Laot Wilayah Paya Keuneukai meliputi satu kelurahan yaitu Kelurahan Paya Keuneukai

i. Panglima Laot Wilayah le Meulee meliputi tiga kelurahan yaitu:

1) Kelurahan Kota Atas

2) Kelurahan le Meulee

3) Kelurahan Ujung Karang 
j. Panglima Laot Wilayah Anoi Itam meliputi satu kelurahan yaitu kelurahan Anoi Itam.

Dalam sistem lembaga Adat Laot Kota Sabang sebenarnya telah mempunyai struktur pemangku adat yang cukup lengkap walaupun di masing-masing wilayah thok yang baru terbentuk karena adanya proses pemekaran terdapat beberapa kesederhanaan dalam struktur kepengurusannya. Panglima Laot Kota Sabang Ismail Thaher menguraikan struktur tersebut antara lain: ${ }^{1}$

\section{a. Panglima Laot Kota}

- 1 (satu) orang Panglima Laot Kota

- 1 (satu) orang Wakil Panglima Laot Kota

- 3 (tiga) orang Penasehat

- 1 (satu) orang Sekretaris

- 1 (satu) orang Wakil Sekretaris

- 1 (satu) orang Bendahara

- 1 (satu) orang Wakil Bendahara

b. Panglima Laot Lhok

- 1 (satu) orang Panglima Laot Lhok

- 1 (satu) orang Wakil Panglima Laot Lhok

- 3 (tiga) orang Penasehat

- 1 (satu) orang Sekretaris

- 1 (satu) orang Wakil Sekretaris

- 1 (satu) orang Bendahara

- 1 (satu) orang Wakil Bendahara

- Ditambah beberapa orang Petugas Keamanan Adat

Sebagaimana disebutkan dalam uraian diatas bahwa Panglima Laot adalah sebagai pemimpin dalam adat kelautan, dan sebagai Pemimpin Sidang dalam persidangan adat, sedangkan Panglima Laot dalam menjalankan fungsi dan tugasnya dibantu oleh seorang wakil panglima yang bertugas membatu Panglima Laot dan bertugas menggantikan tugas dan kewajiban Panglima Laot dalam hal Panglima Laot berhalangan dalam menjalankan tugasnya.

\section{B. Faktor-Faktor Yang Mempengaruhi Pang- lima Laot Dalam Pengelolaan Sumber Daya Alam Laut Di Kota Sabang}

1. Faktor Cara Penangkapan Ikan Dilaut

\footnotetext{
1 Ismail Thahir, Panglima Laot Kota Sabang, Wawancara, 28 Agustus 2008
}

Dalam metode penangkapan ikan dalam perairan Sabang memang terdapat suatu persoalan yang telah lama menjadi masalah yang berat dan tidak kunjung selesai, bahkan persoalan ini sempat dibahas ditingkat komunitas sendiri bahkan sempat diangkat dalam suatu diskusi dengan aparat pemerintah namun sampai dengan saat ini permasalah tersebut tidak juga selesai.

Menurut Kabag Umum Dinas Perikanan dan Kelautan Kota Sabang, Abi Roib bahwa metode penangkapan ikan pada setiap Lhok berbeda-beda, hal ini dapat dilihat dari persoalan-persoalan penagkapan ikan yaitu persoalan ini diawali dari suatu perbedaan pandangan yang sebenarnya sama-sama baik dua wilayah hukum adat seakan telah menjadi dua kubu yang saling bertentangan wilayah le Meulee, Anoi Itam 3 tahun yang lalu mengeluarkan suatu aturan adat berupa larangan penangkapan ikan dengan menggunakan jaring di wilayah le Meulee dan Anoi Itam, dengan alasan bahwa penangkapan dengan menggunakan jaring dapat menimbulkan kerusakan terhadap terumbu karang sedangkan keberadaan terumbu karang diyakini oleh para nelayan le Meulee sebagai tempat berlindungnya ikan-ikan karang, sehingga dengan hancurnya terumbu-terumbu karang maka ikan-ikan di wilayah tersebut menjadi berkurang bahkan hilang. Sedangkan di wilayah Pasiran, Balohan Pria Laot dan Beurawang tidak sependapat dengan aturan adat berupa pelarangan penangkapan ikan dengan menggunakan jarring tersebut karena jarring merupakan alat tangkap tradisional sedangkan hukum adat tidak boleh melarang terhadap metode penangkapan secara tradisional, dan disamping itu perselisihan tersebut di pertajam karena adanya dua musim angin di wilayah Sabang ini sehingga menimbulkan pola penangkapan ikan yang tidak menetap, pada saat musim angin timur maka nelayan yang berada di wilayah pantai timur akan berpindah areal penangkapan ikannya ke wilayah barat begitu juga sebaliknya sehingga bagi nelayan-nelayan pasiran, balohan dan Beurawang yang memang sebagian besar adalah nelayan jarring pada saat 
musim angin barat dimana di bagian pantai barat tidak memungkinkan untuk melakukan penangkapan ikan maka akan berpindah ke wilayah pantai bagian timur yaitu daerah pantai le Meulee dan Anoi Itam sedangkan didaerah tersebut saat ini sudah dilarang untuk melakukan penangkapan ikan dengan menggunakan jarring sehingga dalam kondisi seperti itu mereka tidak dapat melakukan aktifitas penangkapan ikannya ${ }^{2}$.

Rumitnya persoalan antar wilayah karena kedua kubu masing-masing berkeras kepada pendapatnya, Drs. Nasdi Adiansyah mengatakan memang terdapat dua buah solusi yang masih bisa ditempuh antara lain:

a. Dilakukan sebuah riset/penelitian oleh lembaga penelitian yang professional dan independen tentang benar apa tidak penangkapan dengan menggunakan jaring tersebut merusak terumbu karang dan kerusakannya diatas kemampuan laut untuk memperbaikinya;

b. Merubah pola penangkapan ikan secara global terhadap para nelayan di wilayah Pasiran, Balohan, Pria Laot, Keuneukai, Paya, Jaboi dan Beurawang untuk beralih kepada metode penangkapan ikan dengan menggunakan pukat sehingga areal penangkapannya berada di daerah laut yang dalam tidak didaerah pantai. ${ }^{3}$

\section{Faktor Kelembagaan}

Secara kelembagaan lembaga Panglima Laot merupakan lembaga yang sudah sangat tua usianya bahkan telah ada dari sejak jaman Sultan Iskandar Muda, dari dulu hingga sekarang lembaga tersebut tetap eksis dan belum pernah tercatat bahwa lembaga Panglima Laot tersebut mati atau dimatikan oleh pemerintah, namun walaupun demikian pada saat ini lembaga Panglima Laot sudah mulai sangat rapuh, hal ini diakibatkan oleh beberapa hal yang antara lain:

\footnotetext{
2 Abi Roib, Kabag Umum Dinas Perikanan dan Kelautan Kota Sabang, Wawancara, Tanggal 2 September 2008

3 Drs. Nasdi Adiansyah, KADIS Perikanan dan Kelautan Kota Sabang, Wawancara, Tanggal 3 September 2008
}

a. Kewenangan-kewenangan Panglima Laot di era saat ini sudah berubah dari penguasa wilayah perikanan menjadi pengelola wilayah perikanan dalam hubungan koordinatif dengan Pemerintah sebagai penguasa di daerah.

b. Dalam hal pembuatan kebijakan lembaga adat termasuk Panglima Laot jarang sekali diikut sertakan sehingga kebijakan-kebijakan tersebut justru terkadang tidak berpihak kepada lembaga adat.

c. Struktur kepengurusan Panglima Laot semakin tidak teratur hal ini diakibatkan dari tidak adanya aturan yang jelas tentang pengaturan secara kelembagaan.

d. Tidak adanya pemberian suatu pendidikan dan pelatihan dalam hal manajemen organisasi sehingga tata kerja organisasi Panglima Laot terkesan sangat konservatif.

e. Tidak adanya kantor panglima laot.

\section{Faktor Pendapatan Lambaga}

Di samping persoalan-persoalan secara eksternal maka dalam lingkup internal kelembagaan Panglima Laot sebenarnya sangat memprihatinkan Panglima Laot Kota Sabang mengatakan hal ini dilatar belakangi oleh keadaan-keadaan yang antara lain:

a. Tidak adanya anggaran keuangan untuk menjalankan roda organisasi adat tersebut sehingga kebanyakan justru biaya organisasi ditanggung oleh para pengurus

b. Tidak adanya pemasukan kepada kas lembaga adat dari kegiatan-kegiatan perikanan padahal Panglima Laot mempunyai tugas dalam hal mengkoordinir kegiatan-kegiatan perikanan di kalangan para nelayan.

c. Tidak adanya sarana dan prasarana yang dapat mendukung perkembangan organisasi adat Panglima Laot.

d. Tidak adanya insentif yang memadai bagi para pemangku adat laot. ${ }^{4}$

\section{Faktor Batas-Batas Wilayah}

Wilayah Pulo Weh (Kota Sabang) sebenarnya wilayah yang tidak terlalu luas namun dari

\footnotetext{
4 Ismail Thaher, Panglima Laot Kota Sabang, Wawancara, Tanggal Maret 2008
} 
jumlah wilayah hukum adat laot yang tercatat saat ini terdapat 10 (sepuluh) wilayah Panglima Laot Lhok yang ada di Sabang, sehingga pengaturan batas sering menjadi persoalan hal ini sering timbul masalah ketika terjadi penerapan waktu pantang laut khanduri sehingga karena wilayahnya yang terlalu sempit atau karena batas-batasnya yang kurang jelas maka sering terjadi salah pengertian diatara dua wilayah hukum yang saling berbatasan.

Berdasarkan Peraturan tentang PokokPokok Pelaksanaan Kehidupan Adat Laot di sebutkan bahwa batas wilayah ditentukan berdasarkan batas-batas didarat sehingga pada saat sedang melakukan pelayaran dilaut maka sangat sulit untuk menentukan apakah perairan yang dilalui termasuk kepada wilayah hukum yang mana ketika pelayaran tersebut berada dalam wilayah hukum yang berbatasan.

\section{Faktor Sumber Daya Manusia}

Faktor sumber daya manusia (SDM) yang rendah, memang hal ini tidak dapat diingkari karena tingkat pendidikan para nelayan relatif sangat rendah, rata-rata para nelayan tradisional adalah berpendidikan rendah bahkan banyak yang masih buta huruf, hal ini memang sangat mempengaruhi kinerja dan kemampuan produktifitas para nelayan tersebut, terlebih diera serba modern seperti dewasa ini ketertinggalan pendidikan akan sangat berpengaruh terhadap keterbelakangan secara ilmu pengetahuan yang kemudian secara berbanding lurus akan mendorong terhadap faktor kemiskinan.

Salah satu yang menjadi pembatas dari aspek sumber daya manusia adalah kurangnya pendekatan terpadu dan interdisipliner dalam pendidikan dan latihan ilmu kelautan dan perikanan, tidak adanya program yang khusus tentang penglolaan wilayah pantai, kurangnya persiapan ilmu dasar seperti pengetahuan tentang biologi, fisika dan kimia serta kurangnya koordinasi diantara lembaga-lembaga yang menawarkan program yang dapat memberikan pola perikanan yang lebih maju dan modern

Seharusnya pelatihan-pelatihan, ataupun pendidikan tentang pengenalan teknik-teknik perikanan modern harus senantiasa di berikan kepada para nelayan sehingga sedikit banyak mereka akan merubah cara pandangnya terhadap industri perikanan tersebut tidak hanya secara tradisional berdasarkan kebiasaan yang telah berlangsung turun temurun namun harus mulai beralih pada pola industri perikanan yang efektif dan modern.

Peralihan cara pandang bukan berarti harus menghilangkan ciri mereka sebagai komunitas adat, artinya mereka dapat tetap berada dalam suatu nilai-nilai ke-adat-an namun cara kerja mereka yang harus dirubah dengan menggunakan cara-cara dan teknik penangkapan ikan yang modern, misalnya dari sebelumnya mereka menggunakan perahu yang bersifat pergi pagi pulang sore, maka mereka bisa beralih dengan menggunakan perahu atau boat yang lebih besar dan mampu untuk berlayar selama satu minggu, sehingga perbandingan dari hasil tangkapan dengan biaya operasional akan menghasilkan keuntungan dibandingkan dengan berangkat pagi pulang sore dan tentunya harus ada peran pemerintah dalam menunjang alih teknologi dan industri perikanan di kalangan nelayan Sabang.

Di samping itu kita memang telah ketinggalan jauh mengenai industri perikanan, oleh Negara Thailand, mereka nelayannya sudah menggunakan perahu dan alat-alat tangkap yang modern dan canggih sehingga hasil penangkapan mereka bisa sepuluh kali lipat dari hasil tangkapan nelayan Indonesia, hal ini harus kita pikirkan bagaimana kita dapat bersaing dengan mereka atau setidaknya dapat mengikuti pola penangkapan ikan seperti mereka.

Sebagai tolok ukur berhasil atau tidaknya industri perikanan di Sabang dilihat dari taraf hidup para nelayan, karena semua aktifitas perikanan akan berujung pada tingkat kesejahteraan, semakin buruk tingkat kesejahteraan para nelayan semakin kita gagal dalam memanfaatkan sumber daya laut.

\section{Faktor Sistem Manajemen dalam Usaha Perikanan}


210 Jurnal Dinamika Hukum

Vol. 8 No. 3 September 2008

Dalam system usaha perikanan di wilayah Sabang para nelayan masih menggunakan sistem yang konvensional, dimana penjualan ikan masih tergantung pada sistem penjualan toke bangku tanpa adanya menejemen penjualan yang baik sehingga para nelayan selalu harus mengalami resiko dalam hal:

a. Terjadinya penurunan harga ikan

b. Terjadinya keterlambatan penjualan yang mengakibatkan nilai ikan menjadi merosot.

c. Terjadinya pembengkakan biaya operasional dilaut

Sehingga perlu adanya perombakanperombakan secara total dalam system usaha perikanan yang sekarang terjadi di lingkungan para pelaku usaha di bidang perikanan agar adanya sebuah kebijakan yang berorientasi kepada para nelayan.

\section{Faktor Sarana Dan Prasarana Penangkapan Yang Tradisional}

Dalam masyarakat Nelayan di Sabang cenderung masih menggunakan sarana dan prasarana penangkapan ikan yang masih tergolong tradisional sehingga hasil tangkapan mereka sering tidak memuaskan.

Dalam era modern seperti sekarang ini, alih teknologi seharusnya merambah kesemua sector termasuk kepada sektor perikanan, sehingga sedikit banyak akan mendorong kepada perbaikan tingkat kesejahteraan para nelayan, sebagai contoh nelayan di Sabang masih banyak yang menggunakan perahu kecil "katir" dengan sebuah alat pancing, mereka pergi kelaut dengan sarana dan prasarana seperti demikian, maka hasil tangkapan bisa diperkirakan paling hanya cukup untuk memenuhi kebutuhan ikan bagi dia dan keluarganya saja namun tidak ada yang bisa dijual atau dijadikan uang bagi kebutuhan yang lain.

Cara penangkapan yang demikian harus sedikit demi sedikit diarahkan kepada metode penangkapan dengan berorientasi industri artinya mereka harus berorientasi bahwa penangkapan tersebut bukan hanya harus cukup untuk memenuhi kebutuhan dirnya dan keluarga akan ikan, namun juga harus cukup untuk memenuhi kebutuhan yang lainya dari hasil penjualan ikan tersebut.

Padahal cukup banyak saat ini proyekproyek pengadaan kapal bagi nelayan, namun dilihat dari perbandingan berdasarkan kwantitas jumlah nelayan masih jauh dari cukup, disamping itu tingkat pengawasan dan pemeliharaan kapal-kapal yang cukup modern milik pemerintah yang diberdayakan oleh para nelayan kurang begitu dipelihara sehingga cepat mengalami kerusakan, maka pada akhirnya kesadaran ini memang harus berawal dari semua pihak yang dalam hal ini pemerintah dan nelayan (tekong) termasuk semua pelaku ekonomi perikanan

Lembaga hukum adat keberadaannya tidak dapat terlepas dari pemerintah, baik pemerintah pusat maupun pemerintah daerah, karena kelestarian adat istiadat dan hukum adat baik secara langsung maupun tidak langsung sangat bergantung dari kepedulian pemerintah.

Sabang merupakan salah satu daerah kepulauan yang masih memiliki tatanan hukum adat yang hidup dalam masyarakat, sehingga ini sebenarnya menjadi asset yang sangat berharga bagi Pemerintah Daerah Kota Sabang, karena tidak jarang di daerah-daerah lain yang memiliki struktur wilayah yang hampir sama dengan Wilayah Sabang tatanan adatnya sudah tidak terlihat lagi saking banyaknya pengaruh dan desakan dari budaya-budaya yang masuk dari luar daerah tersebut dan yang terpenting Pemerintah Daerah disekitarnya tidak begitu menaruh perhatian terhadap kelestarian adat istiadat tersebut.

Terdapat beberapa harapan dalam Masyarakat Hukum Adat Laot terhadap pemerintah terutama dalam hal:

a. Pemerintah dapat memberikan pengakuan atas eksistensi lembaga adat dan para pemangku adat (Panglima Laot dan jajarannya)

b. Pemerintah dapat memberikan suatu payung hukum yang tegas bagi keberadaan dan kekuatan Hukum Adat Laot dalam masyarakat adat nelayan 
c. Memberikan kesempatan kepada perwakilan pemangku adat untuk ikut memberikan saran dalam kebijakan pemerintah yang menyangkut kelautan (yang berhubungan dengan laut)

d. Memberikan kesempatan kepada para masyarakat adat nelayan untuk menjaga kelestarian laut sebagai tempat penghidupannya dengan cara-cara adat mereka.

Bagi para anggota masyarakat adat merupakan hal yang istimewa ketika mereka diakui eksistensinya dalam struktur masyarakat secara umum, seperti misalkan para pemangku adat bisa senantiasa disejajarkan dengan para pejabat publik lainnya dalam hal berhubungan dengan tata niaga kelautan, atau setidaktidaknya mereka lkut berperan serta dalam menentukan kebijakan terhadap hal-hal yang menyangkut dengan masalah kelautan.

Di samping itu, mekanisme pelaksanaan Hukum Adat Laot ini perlu ada suatu payung hukum secara formil yang bisa melindungi keberadaannya, sehingga meskipun tetap berada dalam wilayah tatanan adat namun dapat memberikan suatu kepastian bagi para anggota masyarakat adat itu sendiri.

Terhadap hal-hal yang berhubungan dengan penentuan kebijakan di bidang kelautan maka pemerintah dapat menempatkan para Pemangku Adat sebagai pihak yang turut serta dalam memberikan saran-saran dan pertimbangan-pertimbangan atas kebijakan yang akan dikeluarkan.

Dalam praktek sering terjadi berbenturan kepentingan dari kebijakan yang dikeluarkan oleh pemerintah, seperti mengenai ijin melakukan penangkapan ikan, Dinas Perikanan pernah mengeluarkan ijin untuk menangkap ikan dengan menggunakan jaring di seluruh Pantai Sabang, padahal, pada wilayah hukum Panglima Laot le meulee, tidak diperbolehkan untuk menangkap ikan dengan menggunakan jaring sehingga timbulah perbenturan antara aturan dalam lembaga adat dengan Keputusan Pemerintah.

Walaupun memang dalam tatanan pelaksanaan mungkin keputusan Pemerintah memiliki daya ikat yang lebih kuat karena merupakan sebuah produk Institusi Negara namun kita tidak dapat sekali-kali mengabaikan kekuatan berlakunya hukum adat, karena hukum adat memiliki pengakuan yang sangat kuat dari para anggota masyarakat adatnya.

Seandainya Lembaga Adat diikutsertakan dalam pengeluaran kebijakan tersebut atau setidaknya memperhatikan bagaimana sistem adat yang berlaku di masing-masing wilayah hukum Adat maka kejadiannya tidak akan menimbulkan persoalan seperti demikian.

Kepentingan para nelayan dengan memberlakukan larangan adat berupa tidak boleh menangkap ikan dengan menggunakan jaring semata-mata adalah untuk melindungi kelestarian ekosistem laut (habitat terumbu karang) karena dengan penggunaan jaring akan menimbulkan rusaknya terumbu karang sebagai rumah-rumah ikan, artinya pemerintah-pun perlu untuk mempertimbangkan aturan-aturan adat yang berlaku di masing-masing wilayah Hukum Adat Laot di Sabang. Maka untuk menghindari persoalan-persoalan di masa yang akan datang perlu diadakan suatu ketentuan yang dapat menjadikan landasan berpijak bagi berlakunya hukum adat, yaitu dengan membuat suatu aturan memgenai mekanisme paksanaan kehidupan adat laut di Sabang.

\section{Penutup}

1. Simpulan

Dalam hal kegiatan sehari-hari, masyarakat nelayan memiliki dan mentaati ketentuan atau norma-norma adat yang berkaitan dengan kegiatan di laut. Norma adat tersebut berlaku secara efektif dan apabila terjadi pelanggaran terdapat mekanisme tersendiri dalam penerapan sanksi adat. Penyelesaian sengketa adat laot oleh panglima laot merupakan salah satu mekanisme penerapan sanksi adat dan menjadi alternatif solusi untuk menyelesaikan kasus tentang pengelolaan Sumber Daya Alam Laut di Kota Sabang. Namun dalam implementasinya terdapat faktor-faktor yang menghambat Panglima Laot dalam pengelolaan Sumber Daya Alam Laut di Kota Sabang, meliputi: faktor cara pe- 
212 Jurnal Dinamika Hukum

Vol. 8 No. 3 September 2008

nangkapan ikan dilaut, faktor kelembagaan, faktor pendapatan lambaga, faktor batas-batas wilayah, faktor sumber daya manusia, faktor lemahnya sistem manajemen dalam usaha perikanan dan faktor sarana dan prasarana penangkapan yang tradisional.

2. Saran

a. Pemerintah Kota Sabang perlu mempersiapkan kebijakan yang berkaitan dengan peningkatan kapasitas kelembagaan Adat Panglima Laot. Beberapa permasalahan kelembagaan diantaranya dukungan ketersediaan anggaran dari Pemerintah Kota Sabang dalam menjalankan organisasi.

b. Panglima Laot Kota Sabang belum memiliki kantor sendiri, oleh karena itu diperlukan pembangunan kantor Panglima Laot secara permanen sehingga memudahkan para nelayan dalam menyampaikan aspirasinya.

c. Pemerintah Kota Sabang dan pihak yang terkait untuk mengadakan pelatihan-pelatihan, ataupun pendidikan tentang pengenalan teknik-teknik perikanan modern sehingga sedikit banyak mereka akan merubah cara pandangnya yang tradisional ke arah pola industri perikanan yang efektif dan modern.

\section{Daftar Pustaka}

Djuned, Teuku dkk. 1995. Pengelolaan Lingkungan Laut oleh "Panglima Laot". Banda Aceh: UNSYIAH;

Muhammad, Adli dkk. 2006. Selama Kearifan Adalah Kekayaan. Banda Aceh: Lembaga Hukum Panglima Laot dan Yayasan KEHATI Indonesia;

Zainuddin, H. M. 2006. Tarich Atjeh dan Nusantara. Medan : Pustaka Iskandar Muda;

Undang-Undang Nomor 11 Tahun 2006 Tentang Pemerintahan Aceh;

Undang-Undang Nomor 31 Tahun 2004 Tentang Perikanan;

Undang-Undang Nomor 44 Tahun 1999 Tentang Penyelenggaraan Keistimewaan Daerah Istimewa Aceh;

Peraturan Daerah Nomor 7 Tahun 2000 tentang Penyelenggaraan Kehidupan Adat; 